\title{
PERFORMANCE ANALYSIS OF A NOVEL PORTABLE SOLAR HYBRID VC REFRIGERATION SYSTEM
}

\author{
Surender Kumar, R.S. Bharj \\ E-Mail Id: surender10161007@gmail.com, bharjrs@nitj.ac.in \\ Department of Mechanical Engineering Department, NIT, Jalandhar (PB), India
}

\begin{abstract}
Humans have always been concerned about the environment and energy conservation. The novel design of a portable solar hybrid vapor compression refrigerator has been proposed in this study. This hybrid energyoperated DC refrigerator was tested with four load conditions on sunny days. The I-V curve of the PV panel, refrigerator chamber temperature and meteorological data were recorded. The solar panel generated an average of $785 \mathrm{Wh}$ of solar energy in one sunny day. The refrigerator was consumed $98 \mathrm{Wh}$ energy at the no-load condition in a single day. The refrigerator chamber was filled with 30\% $(70 \mathrm{~L}), 60 \%(140 \mathrm{~L})$, and $90 \%(210 \mathrm{~L})$ load that consumed $154 \mathrm{Wh}, 316 \mathrm{Wh}$, and $492 \mathrm{Wh}$ energy, respectively to reach $0{ }^{\circ} \mathrm{C}$. Daytime energy consumption of refrigerator was higher as compared to night time. The lead-acid battery's energy storage capacity was $1260 \mathrm{Wh}$. The battery was able to run the refrigerator for 2.5 days with $90 \%$ load condition without solar energy. The refrigeration system's average COP was 1.2. Experimental results demonstrated that solar energy production was higher as compared to refrigerator energy consumption. The proposed unique technology demonstrates the feasibility of the hybridization of renewable energy and grid utility in a cost-effective and environmentally friendly way. This solar-assisted system can be used to store lifesaving medicines and vaccines in disaster-prone areas.
\end{abstract}

Keywords: Mobile solar refrigeration, energy-saving, performance, economic analysis.

\section{INTRODUCTION}

The availability of utilizable sources of energy is essential to every country's technical development and economic prosperity. In recent decades, fossil fuels have been considered and utilized as the primary source of energy. The energy production industry is highly dependent on fossil fuels such as coal, oil, and gas, which are producing large amounts of pollution. However, the adverse environmental effects of burning fossil fuels have forced energy experts to consider renewable energy sources seriously. Solar energy has tremendous potential and inherent availability [1]. Solar energy is an abundant energy resource in Asian countries. Solar energy has a significant positive impact on the world's environment, economics, and politics. Solar refrigeration is a significant application of renewable energy conversion technologies. This type refrigeration system has been gaining popularity around the world since the beginning of the last decade. It is beneficial because cooling demand is higher at times of the day when the availability of solar radiation is maximum [2]. The refrigeration and cooling demand are higher in the summer season.

The market for refrigeration and cooling systems is growing continually. The energy demand for refrigeration systems is rising throughout the world, especially in hotter regions. These systems consume about $30 \%$ of total global energy. Conventional cooling systems are less energy efficient. Therefore, Conventional cooling systems are more responsible for the negative influence on the ecosystem [3]. Refrigeration and cooling devices are consuming $15 \%$ of the total world electricity.

Energy demand is rising in tandem with the economy, population, and per capita energy consumption. Fossil fuels supply a larger amount of the world's energy, which is a significant contributor to global warming. Energyoptimized refrigeration and cooling systems are an urgent need worldwide [4].

One of the most pressing issues facing humanity is feeding the world's fast-growing population. Food preservation is essential for solving world hunger problems. Globally about 37\% of vaccines and $40 \%$ of perishable foodstuffs require refrigeration systems for storage. The vaccination, medications, and perishable foodstuffs are storing at a lower temperature $\left(0-8{ }^{\circ} \mathrm{C}\right)$. Currently, more than one-third of all food produced in the world is wasted, due to the lack of appropriate technologies, very limited access to energy, especially electricity, and affordability. Global losses for fruits and vegetables are estimated to be $45 \%, 35 \%$ for seafood and fish, $30 \%$ for cereals, and $20 \%$ for dairy products and meat.

The electricity cuts frequently in rural areas of developing countries in summer peak hours. Therefore, perishable food, vaccines, and medicine storage have always been big issues due to a lack of appropriate, reliable, and costeffective technologies. Solar hybrid refrigeration (SHR) technology is expected to provide a more reliable, safer, and cleaner form of refrigeration for perishable foods and improve the cold chain for vaccines [5-7]. The usage of this technology in the cold chain saves grid energy. It also reduces the dependency on grid electricity. This type of technology helps to reduce greenhouse gases emission and global warming [8-15]. The primary aim of this paper is to analyze the performance of a solar-assisted hybrid refrigeration system. 


\section{J T R S International Journal of Technical Research \& Science}

\section{REVIEW ON SHR SYSTEM}

Earlier reviews on SHR system are briefed in table 2.1.

Table- 2.1 Review on SHR System Performance

\begin{tabular}{|c|c|c|}
\hline $\begin{array}{c}\text { Year \& } \\
\text { reference }\end{array}$ & $\begin{array}{l}\text { Type of compressor } \& \\
\text { working refrigerant }\end{array}$ & Method \& experimental parameters \\
\hline \multirow[t]{2}{*}{2009 [16] } & $\begin{array}{l}\text { AC compressor }(110 \mathrm{~W}) \\
\text { R134a refrigerant. }\end{array}$ & $\begin{array}{l}\text { - Solar operated domestic refrigerator (SDR); } \\
\text { - The solar intensity with time, solar photovoltaic panel (SPV) } \\
\text { current, and voltage; } \\
\text { - Freezer temperature and ambient temperature; } \\
\text { - COP of the refrigerator with time. }\end{array}$ \\
\hline & \multicolumn{2}{|c|}{$\begin{array}{l}\text { Short description: The COP of the refrigerator was decreased with sunrise; the maximum COP was } \\
\text { recorded } 2.1 \text { at } 7 \mathrm{am} \text {. }\end{array}$} \\
\hline \multirow[t]{2}{*}{$2011[17]$} & $\begin{array}{l}\text { 12V DC compressor; } \\
\text { R134a refrigerant. }\end{array}$ & $\begin{array}{l}\text { - Multi-purpose PV-refrigerator system; } \\
\text { - Solar radiation and PV power; } \\
\text { - Refrigerator-cabin temperature and the ambient temperature. }\end{array}$ \\
\hline & \multicolumn{2}{|c|}{$\begin{array}{l}\text { Short description: The photovoltaic panel produced } 425.9 \mathrm{Wh} / \text { day of energy; the refrigerator } \\
\text { reached }-10.6{ }^{\circ} \mathrm{C} \text { temperature; the refrigerator's energy consumption was } 347.7 \mathrm{Wh} / \text { day for the } 15 \mathrm{~L} \\
\text { load condition. }\end{array}$} \\
\hline \multirow[t]{2}{*}{$2012[18]$} & $\begin{array}{l}\text { 12V DC compressor; } \\
\text { R134a refrigerant. }\end{array}$ & $\begin{array}{l}\text { - PV powered VCR system; } \\
\text { - Speed of compressor; } \\
\text { - Temperature variation time. }\end{array}$ \\
\hline & \multicolumn{2}{|c|}{$\begin{array}{l}\text { Short description: The cooling rate was increasing from } 0.231 \text { to } 0.8^{\circ} \mathrm{C} / \mathrm{min} \text { when the DC } \\
\text { compressor's speed was increased from } 2000 \text { to } 3600 \mathrm{rpm} \text {. }\end{array}$} \\
\hline \multirow[t]{2}{*}{2016 [19] } & $\begin{array}{l}\text { VSDC compressor; } \\
\text { R134a refrigerant. }\end{array}$ & $\begin{array}{l}\text { - AC and DC compressor operated with solar energy; } \\
\text { - Inside chamber temperatures; } \\
\text { - AC and DC refrigerator energy consumption; } \\
\text { - Speed of compressor; } \\
\text { - Solar energy generation in peak hours; } \\
\text { - Pull down-time. }\end{array}$ \\
\hline & \multicolumn{2}{|c|}{$\begin{array}{l}\text { Short description: The Solar operated DC refrigerator system installation cost was } 18 \% \text { less than the } \\
\text { AC refrigerator; the AC refrigerator consumed high power compared to the DC refrigerator. }\end{array}$} \\
\hline \multirow[t]{2}{*}{$2017[20]$} & $\begin{array}{l}\text { 12V DC-VCR compressor; } \\
\text { R134a refrigerant. }\end{array}$ & $\begin{array}{l}\text { - Battery and hybrid mode of energy supply; } \\
\text { - The current and voltage of solar panel; } \\
\text { - Current and voltage consumed by refrigerator; } \\
\text { - Solar radiation and battery voltage; } \\
\text { - The DC refrigerator chamber inside temperature. }\end{array}$ \\
\hline & \multicolumn{2}{|c|}{$\begin{array}{l}\text { Short description: The refrigerator consumed } 15-41 \% \text { more power in loaded condition than the no- } \\
\text { load condition. }\end{array}$} \\
\hline \multirow[t]{2}{*}{2018 [21] } & $\begin{array}{l}\text { 12V DC compressor; } \\
\text { R134a refrigerant. }\end{array}$ & $\begin{array}{l}\text { - Solar-powered DC refrigerator; } \\
\text { - The current and voltage of solar panel; } \\
\text { - Current, voltage consumed by refrigerator; } \\
\text { - Battery voltage. }\end{array}$ \\
\hline & \multicolumn{2}{|c|}{ Short description: The refrigerator's power consumption ranged from 30.84 to $68.16 \mathrm{~W}$. } \\
\hline \multirow[t]{2}{*}{2019 [22] } & $\begin{array}{l}\text { VSDC compressor; } \\
\text { R134a refrigerant. }\end{array}$ & $\begin{array}{l}\text { - Directly coupled vapor compression (DCVC) solar refrigeration } \\
\text { system; } \\
\text { - Compressor speed range } 1800-4200 \mathrm{rpm} \text {; } \\
\text { - Current and voltage generated by the PV panel. }\end{array}$ \\
\hline & \multicolumn{2}{|c|}{$\begin{array}{l}\text { Short description: The COP of the refrigerator was higher }(2.25) \text { at lower compressor speed and } \\
\text { recorded the lowest }(1.85) \text { at higher compressor speed. }\end{array}$} \\
\hline \multirow[t]{2}{*}{2020 [23] } & $\begin{array}{l}\text { DC compressor; } \\
\text { R134a refrigerant. }\end{array}$ & $\begin{array}{l}\text { - Variable speed photovoltaic direct-current (DC) refrigerator; } \\
\text { - Radiation intensity; } \\
\text { - Compressor speed; } \\
\text { - PV power; } \\
\text { - The refrigerator's internal temperature and the outside ambient } \\
\text { temperature. }\end{array}$ \\
\hline & \multicolumn{2}{|c|}{ Short description: Compared with the fixed speed mode, the variable speed mode's cooling capacity } \\
\hline
\end{tabular}


\] $\mathrm{R} S$ International Journal of Technical Research \& Science

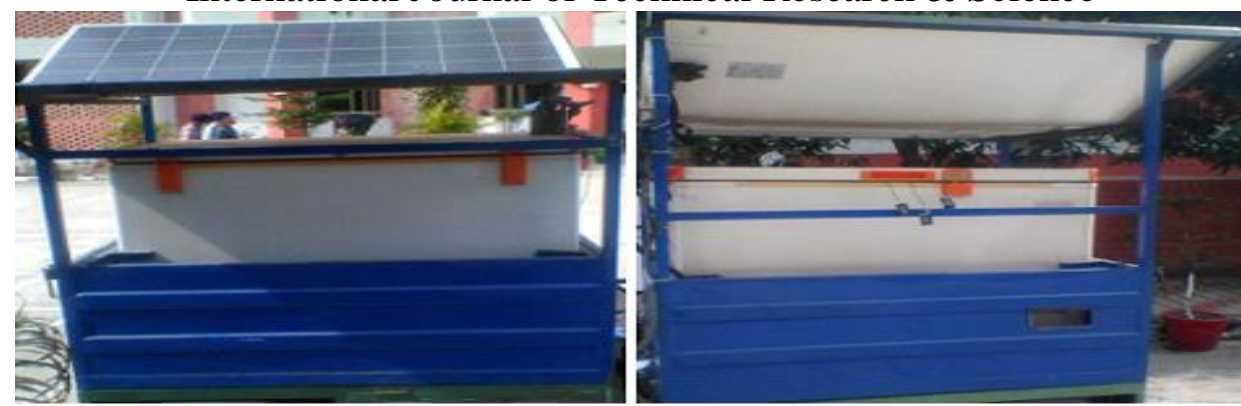

Fig. 3.2 Photographic view of SHR system

Table 3.1 Specifications of SHR system components

\begin{tabular}{|c|c|}
\hline \multicolumn{2}{|c|}{ PV module } \\
\hline Parameter name & Specification \\
\hline Capacity $\left(\mathrm{W}_{\mathrm{P}}\right)$ & $150 \mathrm{~W}$ \\
\hline Module volt $(\mathrm{V})$ & 12 \\
\hline Width (W) & $666 \mathrm{~mm}$ \\
\hline Height $(\mathrm{H})$ & $1483 \mathrm{~mm}$ \\
\hline Thickness (T) & $35 \mathrm{~mm}$ \\
\hline Tolerance & $+/-5 \%$ \\
\hline Module weight & $11 \mathrm{~kg}$ \\
\hline Cell in series & $(9 \times 4) 36$ \\
\hline $\mathrm{V}_{\mathrm{oc}}$ & $21.5 \mathrm{~V}$ \\
\hline $\mathrm{I}_{\mathrm{sc}}$ & $8.75 \mathrm{~A}$ \\
\hline $\mathrm{P}_{\text {Max. }}$ & $150 \mathrm{~W}$ \\
\hline $\mathrm{V}_{\mathrm{pm}}$ & $18 \mathrm{~V}$ \\
\hline $\mathrm{I}_{\mathrm{pm}}$ & 8.33 \\
\hline FF & $>0.70$ \\
\hline Efficency $\left(\eta_{\mathrm{pv}}\right)$ & $>15.0 \%$ \\
\hline \multicolumn{2}{|c|}{ Solar charge controller (MPPT) } \\
\hline System voltage & 24/48 auto recognition \\
\hline Max charge/ load current & $45 \mathrm{~A}$ \\
\hline Efficiency & $90 \%$ \\
\hline \multicolumn{2}{|c|}{ DC refrigerator } \\
\hline Dimensions of outer cabinet & $1145 \mathrm{~mm} \times 850 \mathrm{~mm} \times 690 \mathrm{~mm}$ \\
\hline Inner dimensions & $900 \mathrm{~mm} \times 673 \mathrm{~mm} \times 440 \mathrm{~mm}$ \\
\hline Operating voltage & $12 \mathrm{~V}$ \\
\hline Temperature range & -16 to $+6^{\circ} \mathrm{C}$ \\
\hline Ambient temperature range & 10 to $45^{\circ} \mathrm{C}$ \\
\hline Refrigerant used & R-134a (eco-friendly) \\
\hline Door type & Top opening \\
\hline weight & $58 \mathrm{Kg}$ \\
\hline capacity & $240 \mathrm{~L}$ \\
\hline Insulation & Polyurethane $(12 \mathrm{~cm}$ thick $)$ \\
\hline Compresser type & DC compresser \\
\hline \multicolumn{2}{|c|}{ Lead-acid batterie } \\
\hline Rated output & $105 \mathrm{Ah}, 12 \mathrm{~V}$ \\
\hline Depth of discharge & $80 \%$ (First 1600 cycles) \\
\hline Overall efficiency & $65 \%$ \\
\hline
\end{tabular}

\section{PROCEDURE FOR PERFORMING EXPERIMENTS}

All of the experiments are carried out in an open environment on sunny days. These experiments were carried out in the Mechanical Engineering Department at the National Institute of Technology Jalandhar. These tests were performed between 5-29 September, 2019. The following experimental conditions were maintained: 
† J T R S International Journal of Technical Research \& Science

$>$ All experiments are performed in the same location.

$>$ The thermostat knob was fixed at the 7th position during all refrigerator experiments.

$>$ Before starting each refrigerator experiment, the door of the DC refrigerator is left open for 4 hours to maintain thermal equilibrium with ambient air.

$>$ The door of the DC refrigerator was kept closed throughout the experiment.

$>$ The first experiment was conducted in the refrigerator with no load, then tested with $30 \%, 60 \%$, and $90 \%$ load conditions.

Six thermocouples are installed on the inner wall of the refrigerator to detect temperature. Another temperaturehumidity metre is used to record data about the ambient air. Data from the solar and refrigerator tests are recorded every 30 minutes and every 15 minutes, respectively. The monthly average solar radiation in Jalandhar city is shown in fig. 4.1. The pyranometer is used to measure solar irradiation. The temperature on the surface of the PV panel is measured using a digital non-contact infrared thermometer (temperature gun).

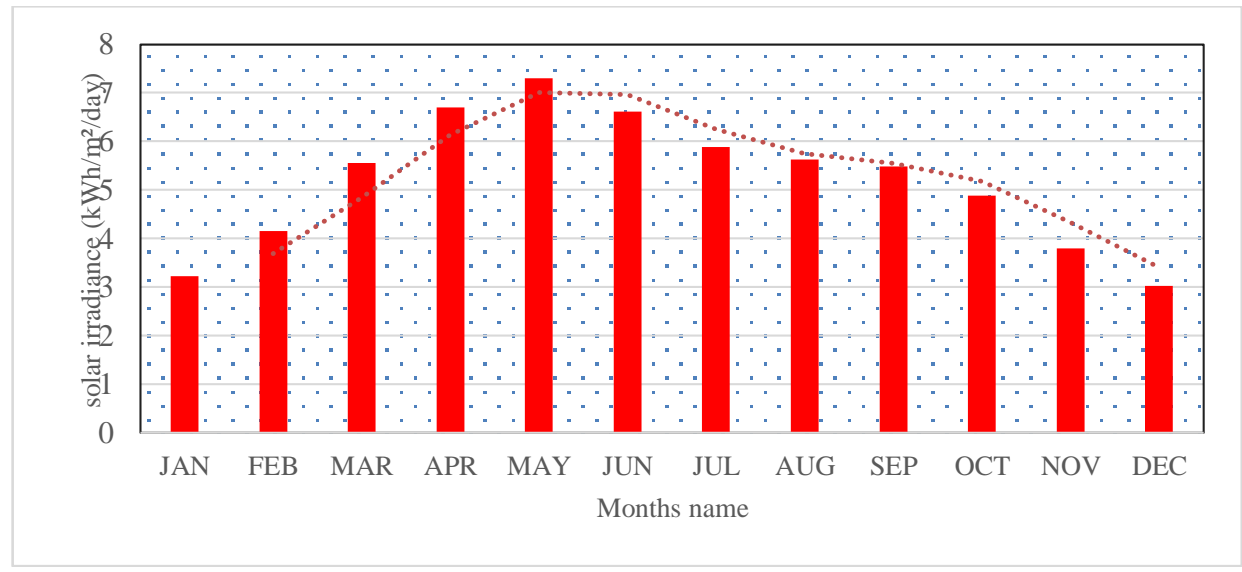

Fig. 4.1 The monthly average solar radiation in Jalandhar city [26]

The variation of meteorological parameters and performance of PV panel in experimental day is shown in figure 4.2. Equations 1 and 2 are used to calculate the power and energy consumed by a refrigerator.

$$
\text { Power }=\text { Current } \times \text { Volatage }
$$

$$
E_{\text {daily }}=\int_{0}^{24 h r s} p \cdot d t=\sum_{t=0}^{24 h r s} p \square t
$$
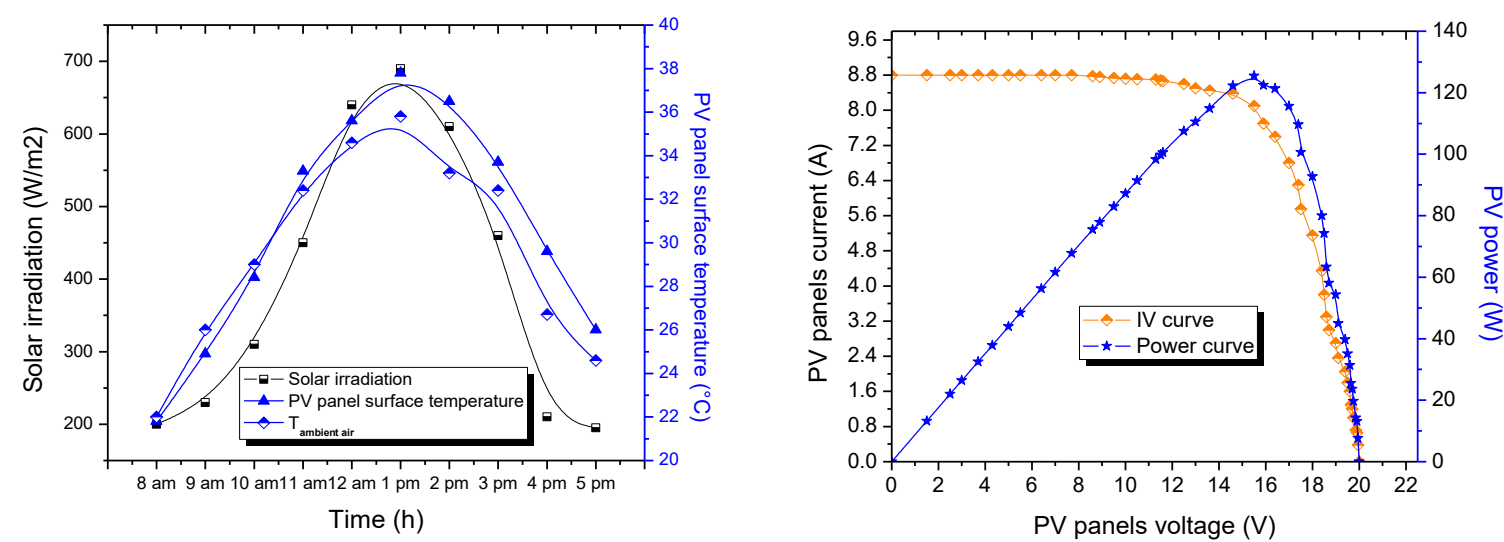

Fig. 4.2 Meteorological parameters variation and performance of $P V$ panel in experimental day

\section{RESULTS AND DISCUSSION}

Experiments are conducted to analyze the performance of the SHR system on sunny days. These tests were carried out in two stages. The performance of the PV panel is tested in the first stage. The refrigeration of this system is tested in the second stage by changing the load situation.

\subsection{The PV Panel Test}

The experiment is carried out on a sunny day between 9:00 a.m. and 5:00 p.m. The PV panel's output current, 
7 J T R S International Journal of Technical Research \& Science

voltage, and power are all measured. The output energy of the PV panel was $785 \mathrm{Wh}$, with output power ranging from 80 to 120 watts.

\subsection{Experiments on the DC Refrigerator}

All experiments are performed under different loading conditions: (1) with no-load (2) with 30\% (70 L) load (3) with $60 \%(140 \mathrm{~L})(4)$ with $90 \%(210 \mathrm{~L})$ load. The current and power consumed by the refrigerator under various loading situations are shown in figures $5.1(\mathrm{a} \& \mathrm{~b})$ and $5.2(\mathrm{a} \& \mathrm{~b})$. The results show that the refrigerator consumed more power when it was operated at $90 \%$ load capacity. The maximum amount of power consumption for no-load, $30 \%$, 60\% load, and $90 \%$ was measured $14.6 \mathrm{~W}, 16.5 \mathrm{~W}, 17.2 \mathrm{~W}$, and $17.8 \mathrm{~W}$ respectively. The current consumption is also recorded higher at $90 \%$ load situation.

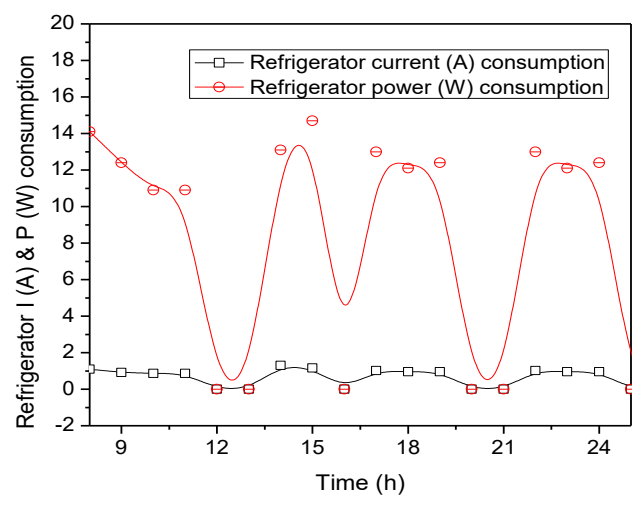

(a)

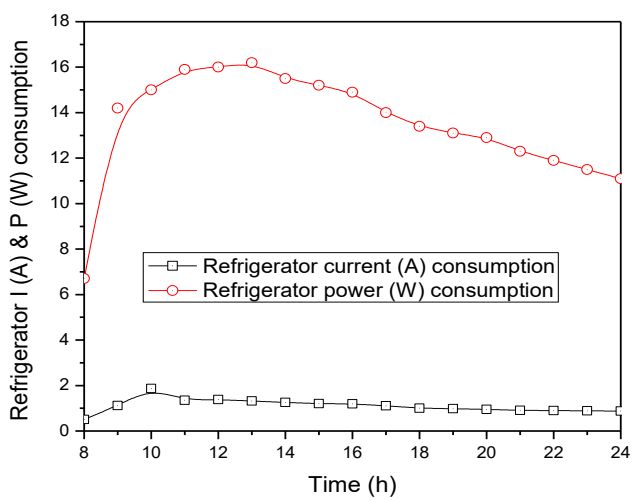

(b)

Fig. 5.1 Current and power consumed by refrigerator (a) at no-load and (b) $30 \%$ condition

Fig. 5.3 (a) shows the inside temperature variation of the refrigerated chamber. The lower temperature $-17{ }^{\circ} \mathrm{C}$ was recorded inside the refrigerator at no-load condition. The refrigerator required more time to reach $0{ }^{\circ} \mathrm{C}$ when the loading quantity is raised. Figure 5.3 (b) shows the energy consumption of the refrigerator. The refrigerator's energy consumption increases when the proportion of load is raised.

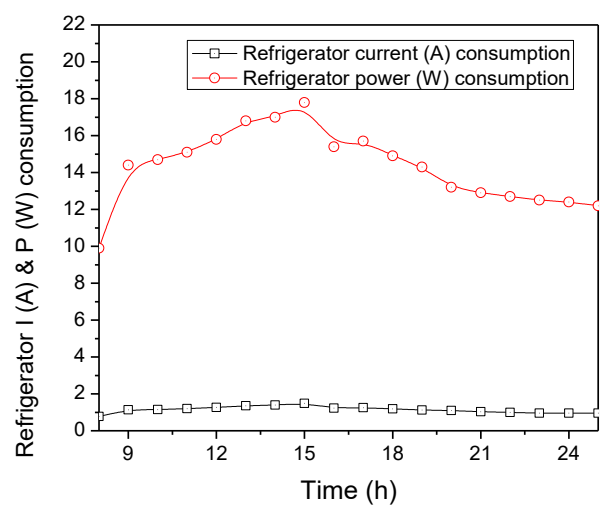

(a)

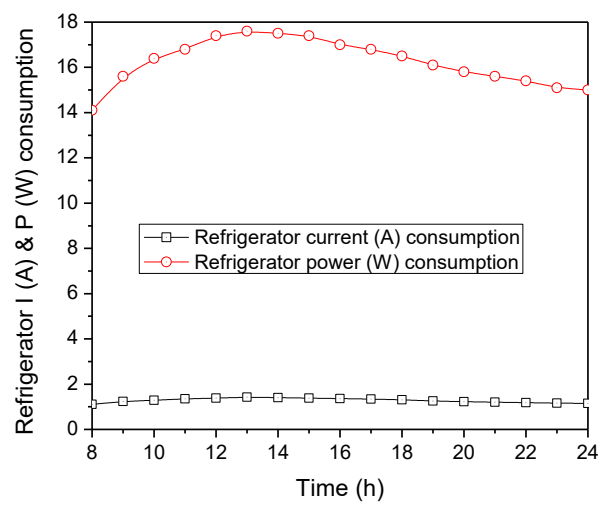

(b)

Fig. 5.2 Current and power consumed by refrigerator (a) at $60 \%$ and (b) $90 \%$ load condition

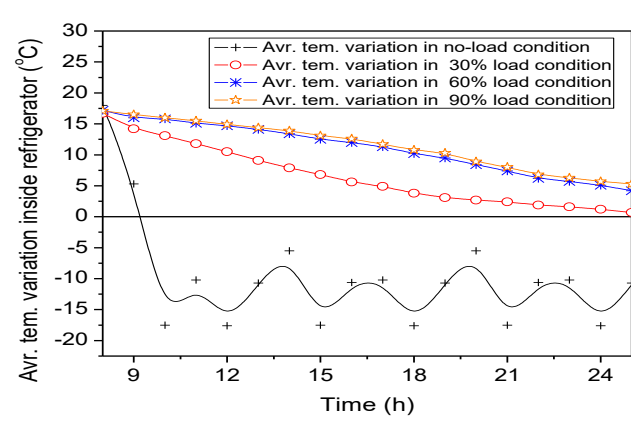

(a)

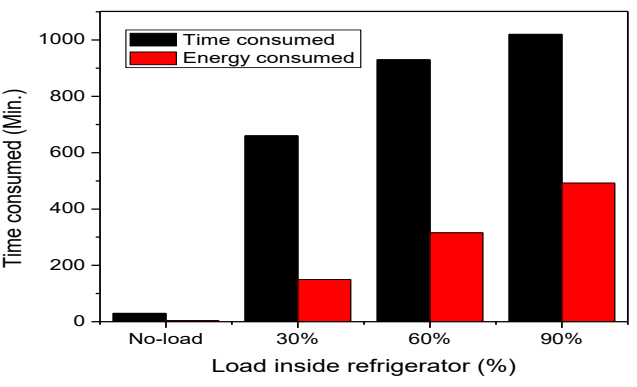

(b)

Fig. 5.3 Refrigerator (a) chamber inside temperature variation (b) energy consumption 


\section{I R S International Journal of Technical Research \& Science}

\subsection{Payback Period of SAR System}

The payback period of the SHR system $=$ Total cost of this system $/$ Total money earns by this system per year.

Total cost of this system in INR $=55000$ (refrigerator cost $)+4500$ (solar penal) +2000 (charge controller $)+5500$ (battery cost $)=67,000$ INR .

Considered 50 INR cooling cost for the different commodities in one day and ten months cooling is required in a year.

Case earns by this system per year $=50$ INR $($ one-day cooling cost $) \times 30$ (days in a month $) \times 10($ cooling required in months in a year) $=15000$ INR

Average energy saved by this system per year $=0.787$ (Panel generated energy in one day) $\times 30$ (days in a month) $\times$ 8 (available solar energy months) $=189 \mathrm{KWh}$

Energy saved by this system in a year $=189 \mathrm{KWh} \times 8 \mathrm{INR}($ per unit cost $)=1512 \mathrm{INR}$

Total money earns by this system per year $=$ Case earns per year + average energy saved per year $=15000+1512$

$=16512$ INR

The payback period of SHR system $=67,000 / 16512=4$ years

\section{CONCLUSION}

The performance and energy consumption of a portable solar hybrid vapor compression refrigerator system was studied under different load conditions. This technology utilized two types of energy sources to run the DC compressor of the refrigerator. The battery was charged using both grid and solar energy. This system's battery was charged using solar energy during the day and grid electricity at night. The following are the most important findings from the experiments:

$>$ Experimental results showed that the SHR system fits to achieve and maintained the lower desire temperature inside the refrigerator chamber at any time.

$>$ The lead-acid battery capacity was $105 \mathrm{Ah}(1260 \mathrm{Wh})$, which was enough to run the refrigerator for 2.5 days at $90 \%$ load without the use of solar energy.

$>$ On a sunny day, the solar panel yielded an average of $65.4 \mathrm{Ah}(785 \mathrm{Wh})$ of solar energy, which was sufficient to charge the battery during the day.

$>$ The battery charged fully in 1.5 days using solar energy.

$>$ The average COP of the refrigeration system was 1.2.

$>$ The temperature variations in different parts of the refrigerated chamber were studied. In a no-load condition, the refrigerated chamber's lower average temperature of $-12{ }^{\circ} \mathrm{C}$ was maintained by consuming $98 \mathrm{Wh}$ of energy in one day.

$>$ For a 30\% load condition, the refrigerator's compressor was reached $0{ }^{\circ} \mathrm{C}$ in 660 minutes by consuming $154 \mathrm{Wh}$ of energy.

$>$ For $60 \%$ load condition, the refrigerator's compressor was reached $0{ }^{\circ} \mathrm{C}$ in 930 minutes by consuming $316 \mathrm{Wh}$ energy.

$>$ For $90 \%$ load condition, the compressor of the refrigerator was reached at $0{ }^{\circ} \mathrm{C}$ in 1020 minutes by consuming 492Wh energy.

$>$ The Payback period of this system was 4 years.

$>$ The running and maintenance costs of this portable refrigeration system were affordable, making it ideal for storing life-saving medications.

\section{REFERENCES}

[1] Said, S.A.M., Spindler, K., El-Shaarawi, M.A., Siddiqui, M.U., Schmid, F., Bierling, B. and Khan, M.M.A., (2016), "Design, construction and operation of a solar powered ammonia-water absorption refrigeration system in Saudi Arabia", International Journal of Refrigeration, 62, pp. 222-231.

[2] Salilih, E.M. and Birhane, Y.T., (2019), "Modelling and performance analysis of directly coupled vapor compression solar refrigeration system", Solar Energy, 190, pp. 228-238.

[3] Alahmer, A. and Ajib, S., (2020), "Solar cooling technologies: State of art and perspectives", Energy Conversion and Management, 214, pp. 1-17.

[4] Leite, G.D.N.P., Weschenfelder, F., Araujo, A.M., Ochoa, A.A.V., Neto, N.D.F.P. and Kraj, A., (2020), “An economic analysis of the integration between air-conditioning and solar photovoltaic systems", Energy Conversion and Management, 185, pp. 836-849.

[5] Gupta, B.L., Bhatnagar, M. and Mathur, J., (2014), "Optimum sizing of PV panel, battery capacity and insulation thickness for a photovoltaic operated domestic refrigerator", Sustainable Energy Technologies and Assessments, 7, pp. 55-67.

[6] Aste, N., Del Pero, C. and Leonforte, F., (2017), "Active refrigeration technologies for food preservation in humanitarian context-A review", Sustainable Energy Technologies and Assessments, 22, pp.150-160. 
$7 \mathrm{~J}$ T $\mathrm{S}$ International Journal of Technical Research \& Science

[7] IRENA, Renewable Energy Benefits: Decentralised Solutions in the Agri-Food Chain, The International Renewable Energy Agency, Abu Dhabi, 2016.

[8] Rech, S., Finco, E. and Lazzaretto, A., (2020), "A multicriteria approach to choose the best renewable refrigeration system for food preservation", Renewable Energy, 154, pp. 368-384.

[9] Lloyd, J. and Cheyne, J., (2017), "The origins of the vaccine cold chain and a glimpse of the future", Vaccine, 35(17), pp.2115-2120.

[10] Li, Y. and Wang, R.Z., (2016), "Photovoltaic-powered solar cooling systems", In Advances in Solar Heating and Cooling (pp. 227-250). Woodhead Publishing.

[11] Prashant Kumar, Vinod Kumar "Economic Analysis of Rural Distribution System with DER and Energy Storage System" 2nd International Conference on Computational Intelligence and Emerging Power System (ICCIPS 2021), Springer Conference, 09-10, March 2021.

[12] Prashant Kumar, Vinod Kumar "Energy storage options for enhancing the reliability of Power system in the presence of Renewable Energy Sources" 2nd International Conference on Inventive Research in Computing Applications (ICIRCA 2020), IEEE Conference, 15-17, July 2020.

[13] Prashant Kumar, Mrs. Shimi S L, Dr. Lini Mathew, Dr. Pushpendra Singh "Need of ICT for Sustainable Development of Power Sector", International Conference on ICT for Sustainable Development (ICT4SD 2015), Ahmedabad, 3-4 July 2015. http://link.springer.com/chapter/10.1007/978-981-10-0129-1_63

[14] Aste, N., Del Pero, C. and Leonforte, F., (2017), "Active refrigeration technologies for food preservation in humanitarian context-A review", Sustainable Energy Technologies and Assessments, 22, pp. 150-160.

[15] Al-Alili, A., Hwang, Y. and Radermacher, R., (2014), "Review of solar thermal air conditioning technologies", International Journal of Refrigeration, 39, pp. 4-22.

[16] Del Pero, C., Butera, F.M., Buffoli, M., Piegari, L., Capolongo, L. and Fattore, M., (2015), "Feasibility study of a solar photovoltaic adaptable refrigeration kit for remote areas in developing countries", In 2015 International Conference on Clean Electrical Power (ICCEP) (pp. 701-708). IEEE.

[17] Coulomb, D., (2008), "Refrigeration and cold chain serving the global food industry and creating a better future: two key IIR challenges for improved health and environment", Trends in food science \& technology, 19(8), pp. 413-417.

[18] Yan, G., Liu, Y., Qian, S. and Yu, J., (2019), "Theoretical study on a vapor compression refrigeration system with cold storage for freezer applications", Applied Thermal Engineering, 160, p. 114091.

[19] Modi, A., Chaudhuri, A., Vijay, B. and Mathur, J., (2009), "Performance analysis of a solar photovoltaic operated domestic refrigerator", Applied Energy, 86(12), pp. 2583-2591.

[20] Aktacir, M.A., (2011), "Experimental study of a multi-purpose PV-refrigerator system", International journal of physical sciences, 6(4), pp.746-757.

[21] Sobamowo, M.G., Ogunmola, B.Y., Ismail, S.O. and Ogundeko, I.A., (2012), "Design and development of a photovoltaic-powered DC vapour compression refrigerator with an incorporated solar tracking system", Int J Mech Comput Manuf Res, 1, pp.19-28.

[22] Opoku, R., Anane, S., Edwin, I.A., Adaramola, M.S. and Seidu, R., (2016), "Comparative techno-economic assessment of a converted DC refrigerator and a conventional AC refrigerator both powered by solar PV", International journal of refrigeration, 72, pp. 1-11.

[23] Daffallah, K.O., Benghanem, M., Alamri, S.N., Joraid, A.A. and Al-Mashraqi, A.A., (2017), "Experimental evaluation of photovoltaic DC refrigerator under different thermostat settings", Renewable energy, 113, pp. 1150-1159.

[24] Tsado, J., Mahmood, M.K., Raji, A.G., Usman, A.U. and Jiya, I.N., (2017), "Solar powered DC refrigerator with a monitoring and control system", In 2018 IEEE PES/IAS PowerAfrica (pp. 591-594). IEEE.

[25] Salilih, E.M. and Birhane, Y.T., (2019), "Modelling and performance analysis of directly coupled vapor compression solar refrigeration system", Solar Energy, 190, pp. 228-238.

[26] Su, P., Ji, J., Cai, J., Gao, Y. and Han, K., (2020), "Dynamic simulation and experimental study of a variable speed photovoltaic DC refrigerator", Renewable Energy, 152, pp.155-164.

[27] Hu, C., Li, M., Wang, Y., Li, G., Ma, X., Du, W., Zhou, X. and Zhang, Y., (2021), "Preliminary investigation on pilot-scale photovoltaic-driven cold storage with ice thermal storage based on vapor compression refrigeration cycle", Sustainable Energy Technologies and Assessments, p.101187.

[28] Li, G., Han, Y., Li, M., Luo, X., Xu, Y., Wang, Y. and Zhang, Y., (2021), "Study on matching characteristics of photovoltaic disturbance and refrigeration compressor in solar photovoltaic direct-drive air conditioning system", Renewable Energy, 172, pp.1145-1153.

[29] https://www.weather2visit.com/asia/india/jalandhar.htm. Retrieved on 20/07/2021. 